\title{
A hibákból és a nemkívánatos eseményekböl való tanulás - módszertani áttekintés a témaspecifikus tanulmányokhoz
}

\author{
Learning from mistakes and adverse events - \\ methodological overview for the topic-specific studies \\ Dr. habil. Belicza Éva1,2, Sinka Lászlóné Adamik Erika1,2, \\ ${ }^{1}$ Semmelweis Egyetem, Egészségügyi Közszolgálati Kar, Egészségügyi Menedzserképző \\ Központ, Budapest, ${ }^{2}$ NEVES Egyesület a Betegbiztonságért, Budapest
}

Az egészségügyi ellátások során kialakuló nem várt események adatainak gyüjtését szolgálja a WHO és az Egészségügyi Minisztérium kezdeményezésére létrehozott NEVES jelentési rendszer. Az ide beérkezett, megtörtént események részletes adatait tartalmazó jelentéseket hét témakörben dolgoztuk fel az általunk kidolgozott, aggregált jelentési adatokra támaszkodó módszertani útmutató alapján. A dolgozat ismerteti ezen módszertan legfontosabb lépéseit és eszköztárát. Ez segíti az intézmények saját adataikra támaszkodó tanulását, a betegbiztonsági intézkedések megfogalmazását és végrehajtását, valamint bevezetőként szolgál a tanulmányok bemutatását célzó cikksorozathoz.

For gathering data regarding adverse events linked to healthcare, the NEVES reporting system was created in response to the initiative of the WHO and the Ministry of Health. The detailed reports of the data of occurred events were analysed in seven topics, based on the methodological guideline relying on aggregate data reporting. This paper presents the most important steps and tools of this methodology. This will help the institutions to learn with the usage of their own data, to formulate and execute patient safety interventions, and serves as an introduction to the studies which will be presented in future papers.

\section{BEVEZETÉS}

Az elmúlt évtizedekben egyre inkább előtérbe került az egészségügyi ellátás biztonsága, különösen az 1999-ben az Institute of Medicine által kiadott, Tévedni emberi dolog (To Err is Human) című tanulmány megjelenését követően [1]. A tanulmány felhívta a figyelmet az ellátás során bekövetkező nemkívánatos események jelentőségére. Publikálása óta egyre erősebb az egyetértés a szakemberek körében, hogy a hibákból és a nemkívánatos eseményekből tanulni lehet és kell annak érdekében, hogy azok jövőbeli ismételt előfordulása megelőzhető legyen, és így az ellátás biztonságosabbá válhasson [2].

Az egészségügyi ellátás során gyakran fordulnak elő olyan események, amelyek veszélyeztetik a betegek egészségi állapotát és életminőségét. Ezeket a nem szándékosan előidézett, és nem tervezett eseményeket (pl. hibásan rögzített betegadat, elcserélt lelet, hibás számolás alapján elkészített keverékinfúzió, a tervezett beavatkozás elmaradása vagy kórházban szerzett fertőzés) összefoglalóan nem várt eseményeknek (incident) nevezzük. Kimenetelüket tekintve előfordulhat, hogy nem okoznak károsodást a beteg számára, de akár hosszú távú, vagy végleges negatív következményei is lehetnek. Ez utóbbi eseteket - amikor a nem várt esemény betegkárosodással is jár - nemkívánatos eseményeknek (adverse event) nevezzük. A károsodás lehet átmeneti vagy tartós egészségi állapot-, illetve életminőség-romlás, esetleg halálozás. A nemkívánatos események tehát az egészségügyi ellátással összefüggésben jönnek létre, azaz nem a betegség szövődményei, nem a természetes biológiai folyamatok részeként kialakuló károsodások. Nemkívánatos esemény pl. a kórházban kialakult nyomási fekély (decubitus); a kórházban szerzett húgyúti fertőzés; a gyógyszer okozta egészségi állapot- vagy életminőség-romlás [3]

A kórházi ellátásban minden 10. beteg esetében kialakul valamilyen nemkívánatos esemény. A különböző kutatások szerint ezek kb. 70\%-a lenne megelőzhető, azaz valamilyen tervezési vagy végrehajtási hiba azonosítható kialakulásuk hátterében. Az előfordulás tehát jelentős, és ennek csökkenését a kiváltó okok feltárásával és kezelésével lehet elérni [3].

Az Egészségügyi Világszervezet (WHO) 2005-ben jelentette meg azt az irányelvét, ami az egészségügyi ellátással összefüggésben kialakult nemkívánatos események gyűjtését és az azokból való tanulást tűzte ki célul [4].

Hazánkban a WHO Magyarországi Irodája és az Egészségügyi Minisztérium a Semmelweis Egyetem Egészségügyi Menedzserképző Központját kérte fel, hogy adaptálja a WHO irányelvét. A nem várt eseményekkel kapcsolatos adatgyűjtést és elemzést támogató NEVES jelentési rendszer (NEVES = NEm Várt ESemények) 2007 óta működik [5].

$A$ jelentések gyűjtése önmagában nem eredményezi a hibák és a nemkívánatos események számának csökkenését. Ehhez szükség van a jelentett adatok elemzésére, a mögöttes okok feltárására és azok ismeretében a lehetséges megelőző intézkedések meghozatalára, azaz az eseményekből való tanulásra.

Bár a világ sok országában működnek jelentési rendszerek [6], az oda érkező adatok módszertani feldolgozásáról és elemzéséről alig ismertek szakirodalmi közlések. A nemzet- 
közi publikációkban az egyedi események oki vizsgálatára vonatkozóan találhatók módszertani szempontok [7, 8] és erre vonatkozóan hazánkban is készült ajánlás 2011-ben [9]. Kutatási eredmények is elsősorban eseti szintű elemzésekre támaszkodva készülnek [10, 11]. A gyüjtött jelentések aggregációja alapján történő tanulási folyamatra vonatkozó módszertani ajánlást nem találtunk.

Az EFOP-1.8.0-VEKOP-17 - Egészségügyi ellátórendszer szakmai módszertani fejlesztése című, 2017-2020 között zajló kiemelt projekt lehetővé tette, hogy kidolgozzunk egy aggregált adatokra vonatkozó módszertani ajánlást, ami útmutatóként szolgálhat a jelentéseket gyüjtő és küldő, illetve a téma iránt érdeklődő egészségügyi szolgáltatók számára [12]. Segítségével az érdeklődők a saját adataikat elemezve meghatározhatják intézményükben az előfordult nem várt események okait, és módszertani segítséget kapnak az okok kezelési lehetőségeinek feltárásához és gyakorlatba ültetéséhez. A projekt keretében ezen módszertan alapján hét témakörben végeztünk aggregált elemzéseket a NEVES jelentési rendszerbe érkezett adatok feldolgozásával. A legfontosabb eredményeket cikksorozat formájában tervezzük publikálni az IME hasábjain. A cikksorozat utolsó darabjában bemutatjuk az itt leírtaktól eltérő, egyedi oki vizsgálat módszertanával végzett kutatásunkat is.

Jelen dolgozat célja, hogy bemutassa a hét témában elkészült, a kiváltó okok és a megelőzési lehetőségek feltárását bemutató tanulmányok elkészítési módszertanát és bevezetőként szolgáljon az egyes témakörök bemutatásához. Dolgozatunk emellett módszertani támogatást nyújthat azon intézmények számára, akik saját adataik alapján kívánnak oki kutatást végezni a további események megelőzése, vagy előfordulásuk mérséklése érdekében.

\section{ADATOK ÉS MÓDSZEREK}

A tanulmányok elkészítésének adatforrásaként a NEVES rendszerbe érkezett jelentések és a szakértői megbeszéléseken elhangzott információk szolgáltak. A kutatásokat az erre vonatkozó módszertani útmutató alapján végeztük el [12], adaptálva azt az adott témakör specifikumaira.

A NEVES jelentési rendszer online felületen keresztül érhető el (http://neves.nevesforum.hu/). Ezen a weboldalon nyílik lehetőség az egészségügyi szolgáltatók számára az egészségügyi ellátással kapcsolatos nem várt események jelentésére 21 elöre definiált témakörben. A felület az egészségügyi szolgáltatók számára regisztrációt követően, ingyenesen elérhető. Az adatszolgáltatás önkéntes, a szoftverbe anonim módon, szankciómentesen lehet jelentéseket küldeni a jelentendő eseményre specifikus adatlapok segítségével [5].

Az adatlapok föbb elemei: az esemény definíciója; szükség szerint annak lehatárolása, hogy milyen eseteket lehet jelenteni; az érintett személlyel/szervezeti egységgel kapcsolatos; valamint az eseménnyel és következményeivel kapcsolatos információk. Az adatlapok szakértők által kidolgozott, előre meghatározott strukturált kérdéseket tartalmaznak, de van lehetőség szabadszöveges válaszadásra, vélemény kifejtésre is. Kötelezően megválaszolandó kérdés nincs [13]

A NEVES jelentési rendszer online felületén az adatbevitelt követően azonnal lehetőség nyílik a már rögzített strukturált adatok statisztikai elemzésére, valamint a saját adatok országos átlagokkal való összehasonlítására is. Az adatok szükség szerint exportálhatók további elemzések készítéséhez.

\section{EREDMÉNYEK}

Az aggregált elemzések esetén a nem várt eseményekből való tanulás föbb lépéseit a következőkben határoztuk meg:

- az elemzésre alkalmas témakörök kiválasztása

- a kutatást végző munkacsoport kialakítása

- a jelentések adatainak statisztikai elemzése

- szakirodalom áttekintése

- az eseményhez vezető folyamat áttekintése

- az események kiváltó okainak meghatározása

- a feltárt okok kezelési lehetőségeinek azonosítása

\section{Az elemzésre alkalmas témakörök kiválasztása}

Aggregált oki kutatások esetében olyan témakör kiválasztása lehetséges, amelyre vonatkozóan statisztikailag feldolgozható esetszám áll rendelkezésre. Ez alapvetően legalább 30 jelentést tételez fel, de mélyebb (pl. korcsoportos, napszak szerinti) elemzések elvégzéséhez ennél lényegesen több esemény ismeretére is szükség lehet. A NEVES jelentési rendszerben az elemzéseink megkezdésekor az alábbi 7 témakör elégítette ki a statisztikai elemezhetőség kritériumát:

- beteg eltűnése, elkóborlása (továbbiakban: elkóborlás, önkényes távozás)

- betegesések

- decubitus (továbbiakban: nyomási fekély kialakulása)

- dolgozót ért bántalmazás

- elmaradt tervezett mútétek

- tűszúrásos sérülések (továbbiakban: éles, hegyes eszközök okozta sérülések)

- újraélesztés.

\section{A kutatást végző munkacsoportok kialakítása}

A kutatások lebonyolításához 3-4 fős munkacsoportokat hoztunk létre. Tagjai betegbiztonsági és minőségfejlesztési ismeretekkel rendelkeztek, illetve legalább egy-egy tag az adott témában szakmai gyakorlati ismeretekkel, illetve szakirodalom kutatási tapasztalatokkal is bírt. A munkacsoport a módszertani útmutatóra [12] támaszkodva meghatározta a kutatás főbb lépéseit, illetve a szerzett tapasztalatok alapján ajánlást tett az útmutató kiegészítésére, módosítására is.

A kutatás során felmerülő szakmai kérdések tisztázására, valamint a vizsgált témákkal kapcsolatos szakértői vélemények megismerésére fókuszcsoportos megbeszéléseket szerveztünk, témánként két alkalommal. A fókuszcsoportba témánként 6-10 főt hívtunk meg olyan szakemberek közül, 
akik aktuális ellátási tapasztalattal rendelkeznek a vizsgált eseményekkel kapcsolatban. Külön figyelmet fordítottunk arra, hogy a résztvevők között lehetőleg minden érintett munkakör képviselöje jelen legyen. A megbeszéléseket az adott kutatás vezetője moderálta. A fókuszcsoportos alkalmakról részletes feljegyzés készült.

\section{A jelentések adatainak statisztikai elemzése}

$A z$ aggregált (összesített) adatelemzés alapját a NEVES rendszerbe érkezett jelentések képezték. Tekintettel arra, hogy az intézmények által rögzített adatok anonim módon kerülnek a rendszerbe, a kutatás során az összesített, országos adatokkal dolgoztunk.

A kutatás megkezdésekor a vizsgált téma jelentett adatait Excel fájlban exportáltuk a NEVES jelentési rendszerből, majd duplikátumszürést, valamint kitöltöttségi és adatvaliditási vizsgálatot végeztünk. Az adatok feldolgozásához az IBM SPSS és a Microsoft Excel szoftvereket használtuk.

Az összes eseményre vonatkozó jellemzők bemutatására általános leíró statisztikákat készítettünk. A szabadszöveges válaszokat a könnyebb elemezhetőség érdekében kategóriákba soroltuk. Megoszlási viszonyszámokkal elemeztük az események különböző jellemzőinek belső struktúráját. A képzett indikátorokat összehasonlítottuk betegjellemzők, osztálytípusok, napszakok, az esemény előtti történések stb. szempontjából. Kereszttáblákkal vizsgáltuk az egyes kérdésekre adott válaszok közötti logikai kapcsolatokat és a koncentrálódásokat, illetve ezt a módszert használtuk a szélsőségek (outlierek) azonosítására is. Az adatok közötti összefüggések erősségének elemzését khi-négyzetpróbával végeztük.

Az adatok elemzésének alapvető célja az ismétlődő mintázatok feltárása volt az események oki struktúrájában, így lehetővé vált a működésből adódó, rendszerszintű okok megtalálása. Emellett az adatokból információhoz jutottunk a bekövetkezett események súlyosságával és következményeivel, valamint megelőzési lehetőségeivel kapcsolatban.

\section{A szakirodalom áttekintése}

A vizsgált témákhoz kapcsolódó szakirodalom áttekintésének célja az oki kutatás támogatása volt: ezen belül az adott nem várt esemény kialakulásában szerepet játszó okok és hozzájáruló tényezők kigyűjtése, a probléma kialakulásának megelőzését célzó intézkedések, jógyakorlatok összegyüjtése, esetlegesen ezen intézkedések bevezetésének sikerességét támogató vagy korlátozó tényezők feltárása.

A kutatás fókuszainak egyeztetését követően a munkatársak megalkották a téma kulcsszavait és a keresőkifejezéseket tartalmazó listát. Ezt követte a publikációk keresése a hazai és a nemzetközi adatbázisokban. A hazai közlemények keresésére jellemzően a MATARKA (Magyar folyóiratok tartalomjegyzékeinek kereshető adatbázisa), az MTMT (Magyar Tudományos Művek Tára) és a Magyar Orvosi Bibliográfia felületeit használtuk. Emellett a témához kapcsolódó jogszabályok és a NEVES Fórumokon elhangzott előadások kézi keresésére is kiemelt figyelmet fordítottunk. A külföldi adat- bázisok közül a leggyakrabban a PubMed, az Ovid és az EBSCO host Cinahl oldalain kerestünk. A keresés eredményeit egy előzetesen elkészített sablon alapján találati összegző táblázatba gyűjtöttük, a kutatás szempontjából releváns információkat rögzítettük, majd ezek alapján szöveges összefoglalókat készítettünk.

\section{Az eseményhez vezetö folyamat áttekintése}

Az oki kutatás elvégzésének támogatására folyamatelemzést végeztünk. Mivel a különböző folyamatok lépéseit nagyban befolyásolják az intézményi körülmények, az országos adatok mellé részletes és a teljes folyamatot lefedő elemzést nem tudtunk készíteni. A módszer használatának bemutatásához egy-egy olyan részfolyamatot választottunk, amit biztosan mindenhol ugyanúgy lehet/kell csinálni és értelmezni, ezeken keresztül szemléltettük a kockázatos lépések és a döntési pontok azonosításának szerepét az oki kutatás végzésében.

\section{Az események kiváltó okainak meghatározása}

A vizsgált nem várt események okainak összegyűjtéséhez forrásként felhasználtuk a NEVES rendszer jelentéseiből készült statisztikai feldolgozás eredményeit, illetve az abból levonható következtetéseket; a szakirodalmi kutatás eredményeit; valamint a fókuszcsoportos megbeszéléseken részt vevő kollégák szakmai tapasztalatait. Tekintettel arra, hogy nem egy konkrét intézmény adatait elemeztük, hanem az országos aggregált adatokat, a működés speciális vonatkozásainak ismerete hiányában általános okok meghatározására volt lehetőség az intézményekre specifikus gyökérokok azonosítása helyett. Ezért a kutatás során arra törekedtünk, hogy bemutassunk minden olyan okot, amely a munka során az esemény kiváltójaként felmerült, ismertessük az ok-okozati összefüggéseket, az oki láncolatot, és egyúttal megmutassuk azt, hogy egy adott intézmény a saját adatainak feldolgozásakor hogyan járjon el. Az oki kutatáshoz alkalmazott eszköz az ok-hatás (Ishikawa) diagram volt.

Intézményi szinten az alapvető (gyökér-) okok meghatározását követően a kezelendő okok kiválasztására van szükség. Ennek ajánlott eszköze a kockázati mátrix, ami a kiváltó ok elöfordulási gyakorisága és potenciális következményei alapján teszi lehetővé annak megállapítását, hogy mely okokkal célszerủ elsőként foglalkozni az adott esemény visszaszorítása érdekében. Ilyen rangsorolást országos aggregált adatok esetében nem tudunk végezni a megismert lehetséges okok között, így a megoldási lehetőségek megfogalmazásához valamennyi feltárt okot figyelembe vettük. A kockázati mátrix használatára vonatkozóan példákat mutatnak be a tanulmányok.

\section{A feltárt okok kezelési lehetőségeinek azonosítása}

A munka során kigyüjtöttük a NEVES jelentési rendszerből származó, a jelentéseket küldő személyektől érkezett megelőzési javaslatokat, áttekintettük a szakirodalom ide vonatkozó ajánlásait, és listáztuk a kutatást végző munkacsoport, valamint a fókuszcsoportos megbeszélésre felkért 
szakértőink gyakorlati tapasztalataira épülő intézkedési lehetőségeket is.

A megelőzési lehetőségekből összeállított intézkedési javaslatokat prioritási mátrix segítségével értékeltük az intézkedés várható eredményessége szempontjából. A jobb megértés érdekében példákon keresztül illusztráltuk a tanulmányokban a módszer használatát.

\section{MEGBESZÉLÉS}

A nemzetközi gyakorlatban működtetett jelentési rendszerek sokfélék: vannak kötelező és önkéntes rendszerek, minden incidensre kiterjedők, vagy csak a súlyos kimenetelű eseményeket gyűjtők, a jelentők lehetnek csak a dolgozók vagy bárki, aki az esetről tudomást szerez. A jelentések szakmai tartalma is jelentősen eltér egymástól, bár többnyire szabad szöveges leírásokat várnak a rendszerek [6]. Az mindenképpen közös a nemzetközi programokban, hogy a beérkezett jelentések feldolgozása időigényes és jelentős humán erőforrás és költség igénye van [14]. A magyar rendszer különleges abból a szempontból, hogy csak megadott témakörökben lehet jelentést küldeni, és olyan előre kidolgozott adatlapokat töltenek ki az intézmények, amelyek segítségével az esetekhez vezető leggyakoribb történések, okok, körülmények statisztikailag elemezhetők emberi erőforrás igénye nélkül is.

A nem várt események jelentésének és elemzésének akkor van értelme, ha azok feldolgozásra kerülnek, és az eredmények alapján intézkedés történik a hasonló események elkerülése érdekében az érintett szervezeti egységekben. Ehhez nyújthat segítséget az országos jelentési rendszer adatainak elemzése, az események hátterében álló kiváltó okok és lehetséges kezelési lehetőségeik azonosítása.

A jelentési rendszerekkel kapcsolatos közlések többsége elsősorban a jelentett események jellemzőivel foglalkozik, kevés közlés ismert, ami az okok kutatását és kezelési lehetőségeit ismerteti. Ilyen példaként lehet említeni az Egyesült Államokban működő Joint Commission sentinel event (súlyos kimenetellel járó nemkívánatos események) jelentési rendszerét. $A$ beérkezett egyedi jelentéseket feldolgozzák és a megállapítható leggyakoribb kiváltó okokra vonatkozó ajánlásokat (alert) publikálják [15].

A nemzetközi gyakorlatban a jelentési rendszerek hasznosulásával - azaz a belölük való tanulással és ez alapján az események visszaszorulásával - kapcsolatban több korlát is azonositható: a jelentések és az értékelések hiányosságai; a szisztematikus oki kutatások hiánya; az intézkedési tervek és bevezetendő intézkedések azonosításának a hiánya; a képesség és a szándék hiánya az intézkedések megvalósítására [16]. Hazai jelentési rendszerünkre támaszkodó tanulmányaink és a jelen módszertani ismertetőnk segítheti az intézményeket az eseményekből való tanulási folyamatban: az okok feltárásában és a szükséges intézkedések azonosításában.

Minden intézkedés valamilyen, az aktuálistól eltérő gyakorlat kialakítását jelenti, azaz változást, változtatást generál, ami a dolgozók ellenállásába ütközhet, illetve a megvalósítást nehezítheti a végrehajtási feltételek hiánya is.

Tanulmányainkban ezért általános útmutatást is megfogalmaztunk a változtatások előkészítésére, lebonyolítására és az elért eredmények értékelésére és fenntartásra vonatkozóan. Az intézmények az ajánlások alapján ki tudják választani a releváns intézkedéseket és a változtatásvezetési szempontok figyelembevételével azokat meg is tudják valósítani.

A hibákból és a nemkívánatos eseményekből való tanulás nem csupán az adott esemény előfordulási valószínúségét csökkenti, de olyan gondolkodásmódot, szemléletet ad a fejlesztésben közreműködők számára, ami más nem várt események elkerüléséhez is hozzájárul.

\section{A KUTATÁS KORLÁTAI}

Az anonim jelentési rendszerből adódóan nem állt módunkban a feldolgozott adatok validitásának ellenőrzése és nem ismerjük azt sem, hogy a jelentések hány intézménybő érkeztek. Amennyiben egy adott intézmény jelentései jelentős arányt képviselnek az összes jelentett eseményen belül, az ő intézményi sajátosságaik torzító tényezőként jelenhettek meg az országos adatokban. Az országos adatokból egy-egy konkrét intézményre vonatkozóan általános megállapítások nem vonhatók le.

Mivel a jelentési rendszer használata önkéntes és az anonimitás miatt az sem állapítható meg, hogy milyen volumenű volt az érintett beteg- vagy dolgozói populáció, a jelentett események számából azok előfordulási gyakoriságára következtetni nem lehet. Tekintettel arra, hogy a kutatásokban az események oki hátterét vizsgáltuk és nem azok gyakoriságát, ez a kutatás eredményeit nem befolyásolta.

\section{ÖSSZEGFOGLALÁS}

Az egészségügyi ellátáshoz kapcsolódó, nem várt eseményekre épülő kutatásokat az országos NEVES rendszerbe jelentett adatokra, szakirodalmi forrásokra és a szakértő egyeztetésekre alapoztuk. Munkánk során különböző minőségfejlesztési módszereket alkalmaztunk (folyamatábra, okhatás diagram, kockázati mátrix, priorálás, fókuszcsoport), a statisztikai elemzések során indikátorokat képeztünk az okok feltárására. Törekedtünk arra, hogy a látókörünkbe került összes okot és megelőzési lehetőséget összegyűjtsük és bemutassuk, de az egyes intézmények működési sajátosságai további kockázatokat és lehetőségeket rejthetnek magukban. Ezért minden intézmény esetében javasolt megvizsgálni az ott előfordult események részleteit, alkalmazva az itt bemutatott módszereket, eszközöket, de meghagyva annak a lehetőségét, hogy új aspektusok merülhetnek fel.

A munkához segítséget jelenthetnek a kutatott témakörökben készített tanulmányok (ezeket az adott témakörben közzétett publikációkkal egyidőben tesszük elérhetővé), valamint a „Módszertani útmutató az oki kutatások készítéséhez” címü összefoglaló [12]. 
[1] Kohn LT, Corrigan JM, Donaldson MS (Eds): To Err is Human: Building a Safer Health System. Institute of Medicine Committee on Quality of Health Care in America, National Academies Press, Washington (DC), USA, 2000.

[2] Belicza É, Lám J: Egészségügyi minőségbiztosítás. Semmelweis Egyetem, Budapest, 2013. https://info.nevesforum.hu/wp-content/uploads/2018/03/Egészségügyiminőségbiztosítás.pdf (megtekintve: 2021. október. 27.)

[3] Belicza É, Lám J (szerk.): Betegbiztonság a gyakorlatban. Hallgatói jegyzet. Semmelweis Egyetem, Budapest, 2021. https://info.nevesforum.hu/wp-content/uploads/2021/06/ Betegbiztonsag-jegyzet.pdf (megtekintve: 2021. okt. 27.)

[4] WHO draft guidelines for adverse event reporting and learning systems: from information to action. World Health Organization, Geneva, 2005.

[5] Belicza É, Lám J, Sinka LAE és mtsai: A NEVES program. Jegyzet a kötelező szakmacsoportos továbbképzések támogatására. Semmelweis Egyetem, Budapest, 2018. https://info.nevesforum.hu/2018/03/a-neves-program-eloadas-es-jegyzet-a-kotelezo-szakmacsoportos-tovabbkepzesi-tanfolyam-tamogatasahoz/ (megtekintve: 2021. okt. 27.)

[6] Key findings and recommendations on reporting and learning systems for patient safety incidents across Europe. Report of the Commission's working group on patient safety and quality of care. 2014.

[7] Pham JC, Hoffman C, Popescu IC, ljagbemi OM: Concise Incident Analysis Tool: A Resource for Health Care Organization. Canadian Patient Safety Institute, 2014. https://doi.org/10.1016/s1553-7250(16)42003-9

[8] Charles R, Hood B, Derosier JM et al.: How to perform a root cause analysis for workup and future prevention of medical errors: a review. Patient Safety in Surgery, 2016. 10: 20 https://doi.org/10.1186/s13037-016-0107-8

[9] Belicza É, Bodnár Á, Kárpáti E és mtsai.: Ajánlás adott intézményben kialakult és ott észlelt, súlyos kimenetelü nemkívánatos eseményt követő eljárásra vonatkozóan NEKED (Nemkívánatos Események Kezelésére Vonatkozó EljárásrenD), GYEMSZI\&SE EMK, 2012.

https://info.nevesforum.hu/wp-content/uploads/2015/ 12/neked_ajanlas_final.pdf (megtekintve: 2021. 11. 09.)

[10] Wagner C, Merten H, Zwaan L et al.: Unit-based incident reporting and root cause analysis: variation at three hospital unit types. BMJ Open 2016; 6: e011277. https://doi.org/10.1136/bmjopen-2016-011277

[11] Smits M, Zegers M, Groenewegen P et al.: Exploring the causes of adverse events in hospitals and potential prevention strategies. Qual Saf Health Care 2010. 19: e5 http://dx.doi.org/10.1136/qshc.2008.030726

[12] Sinka LAE, Pitás E, Belicza É: Módszertani útmutató az oki kutatások előkészítéséhez. Egészségügyi Ellátórendszer Szakmai Módszertani Fejlesztése (EFOP-1.8.0VEKOP-17-2017-00001). Semmelweis Egyetem Egészségügyi Menedzserképző Központ. https://info.nevesforum.hu/2020/02/modszertani-utmutatooki-kutatasok-vegzesehez/ (megtekintve: 2021. okt. 27.)

[13] Lám J, Sümegi V, Surján C et al.: A jelentő- és tanulórendszerek szerepe a betegbiztonság javításában. Orv. Hetil, 2016. 157: 1034-1041 https://doi.org/10.1556/650.2016.30448

[14] Carter AW, Mossialos E, Darzi A: A national incident reporting and learning system in England and Wales, but at what cost? Expert Review of Pharmacoeconomics \& Outcomes Research, 2015. 15: 365-368. https://doi.org/10.1586/14737167.2015.1031114

[15] https://www.jointcommission.org/resources/patient-safetytopics/sentinel-event (megtekintve: 2021. október 27.)

[16] Drupsteen L, Hasle P: Why do organizations not learn from incidents? Bottlenecks, causes and conditions for a failure to effectively learn. Accident Analysis and Prevention, 2014. 72: 351-358. https://doi.org/10.1016/j.aap.2014.07.027

\section{A SZERZŐK BEMUTATÁSA}

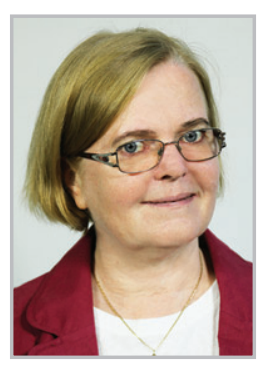

Dr. habil. Belicza Éva a Semmelweis Egyetem Egészségügyi Menedzserképző Központ egyetemi docense, a Betegbiztonsági Tanszéki Csoport vezetője, a minőségügyi és betegbiztonsági menedzser szakirányú továbbképzés programvezetője, a NEVES Egyesület a Betegbiztonságért elnöke. Több minőségügyi és betegbiztonsági témájú projekt szakmai vezetője, hazai és nemzetközi kutatás közreműködője, a NEVES program elindítója. Fő kutatási területe az egészségügyi szolgáltatók minőségértékelése. Rendszeresen publikál szaklapokban, több hallgatói jegyzetet és tankönyvfejezetet írt az egészségügyi minőségbiztosítás és a betegbiztonság témaköreiben.

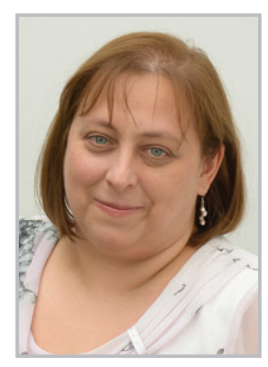

Sinka Lászlóné Adamik Erika 16 éven át dolgozott a közvetlen betegellátásban ápolói és asszisztensi szerepkörökben, majd 8 évig egy kórházi minőségügyi rendszer működtetésében vett részt. Közreműködött a hazai fejlesztésű BELLA akkreditációs standardok kialakításában. A Semmelweis Egyetem Betegbiztonsági Tanszéki csoportjának tagja, részt vesz oktatói és tutori feladatokban, betegbiztonsági témájú kutatásokban, projektekben. A NEVES Egyesület a Betegbiztonságért titkára. 